\title{
Integrity and Character of Contemporary Students in Reflection
}

\section{Fachri Zulfikar, Hermanu Joebagio, Djono}

Universitas Sebelas Maret

felsano24@gmail.com

\section{Article History}

accepted 1/09/2020

approved 4/10/2020

published 1/12/2020

\begin{abstract}
This article is motivated by the phenomenon of contemporary students in the era of globalization who are starting to leave the Indonesian character. Higher education institutions that print the nation's future assets are required to move with character education. Character education teaches how to think and behave so that they become useful individuals in society and contribute as good citizens. Character education has religious values, nationalism, integrity, independence and mutual cooperation. Character education must continue to be strong in a sustainable, sustainable and balanced manner in order to produce students with character, independence and integrity.
\end{abstract}

Keyword: Character, education character, university

\section{Abstrak}

Artikel ini dilatarbelakangi oleh fenomena mahasiswa kekinian di era globalisasi yang mulai meninggalkan karakter adat ketimuran. Perguruan tinggi yang mencetak asset masa depan bangsa wajib bergerak dengan memperkuat pendidikan karakter. Pendidikan karakter mengajarkan cara berfikir dan berperilaku sehingga menjadi individu yang berguna dalam masyarakat serta memiliki kontribusi sebagai warga negara yang baik. Pendidikan karakter memiliki nilai religius, nasionalisme, integritas, kemandirian dan kegotong royongan. Pendidikan karakter harus terus dilatih secara serius, berkelanjutan dan seimbang agar menghasilkan mahasiswa yang berkarakter kuat, mandiri dan beritergritas.

Kata kunci: Karakter, pendidikan karakter, perguruan tinggi

Social, Humanities, and Education Studies (SHEs): Conference Series https://jurnal.uns.ac.id/shes

p-ISSN 2620-9284

e-ISSN 2620-9292 


\section{PENDAHULUAN}

Pendidikan memiliki peran yang sangat penting dalam mengembangkan kepribadian seorang individu maupun kelompok. Pendidikan pada dasarnya dapat membuat manusia menjadi harmonis sehingga dapat mengubah manusia dari kemiskinan, ketertinggalan, kebodohan, kekerasan, dan peperangan, begitu pula dengan pendidikan karakter. Menurut Kemendiknas (2011) Pendidikan karakter memiliki tujuan untuk mengembangkan nilai-nilai berdasarkan karakter bangsa dan berbasis pada Pancasila.

Karakter tentu saja tidak menentukan eksistensi dan kemajuan seseorang, tetapi merupakan eksistensi dan kemajuan sekelompok orang, seperti sebuah bangsa. Ibarat individu, pada hakikatnya setiap bangsa memiliki karakternya tersendiri yang tumbuh dari pengalaman bersama. Ramli (2003) menambahkan pendidikan karakter mempunyai dasar dan tujuan yang sama dengan pendidikan moral dan pendidikan akhlak. Membentuk pribadi anak merupakan tujuan pendidikan karakter, sehingga menjadi individu yang berguna dalam masyarakat serta memiliki kontribusi sebagai warga negara yang baik.

Perguruan tinggi merupakan sebuah tempat belajar serta sebagai wadah dalam mengubah sebuah karakter manusia. Perguruan tinggi merupakan tempat peralihan seorang individu yang awalnya bergelar siswa mendapatkan gelar baru sebagai mahasiswa. Dari definisi diatas, perguruan tinggi terlihat sangat elok dan sangat begitu indah. Terlihat demikian karena perguruan tinggi merupakan gudang yang akan mencetak sebuah individu dengan berbagai keahlian khusus serta memiliki berbagai disiplin ilmu.

Seorang siswa yang mendapatkan gelar mahasiswa merupakan sebuah gelar yang prestisius dan keren. Dengan kata 'maha' tersebut dianggap sudah memeliki kecerdasan berfikir, emosi serta kecerdasan bertindak. Tetapi banyak 'maha'siswa yang tidak dapat menggunakan gelarnya secara baik hingga melakukan kegiatan yang negative. Tentu saja dengan kegiatan negative tersebut membuat kecerdasankecerdasan tersebut sedikit terganggu. Seperti halnya mahasiswa yang tidak mengedepankan adab terhadap dosen. Ini menunjukkan bagaimana adanya kemerosotan sopan santun yang ada dalam diri mahasiswa. Jika sebelumnya saat menjadi siswa begitu hormat kepada bapak ibu guru, maka pada saat dikampus mahasiswa bersikap begitu acuh tak acuh terhadap dosen seakan-akan telah mampu menandingi seorang guru atau dosen. Sangat mungkin, ini terjadi karena persoalan salah menafsirkan gelar 'maha' tersebut sehingga membuat seorang mahasiswa merasa bahwa dirinya sama dengan dosen. Apalagi jika sang dosen kurang dalam penilaiannya, maka muncullah sikap semacam acuh tak acuh dan mulai tidak menghargai dosen. Dan inilah yang kini banyak menjadi penyakit dalam diri seorang mahasiswa.

Mahasiswa memiliki berbagai julukan pada masa kini. Salah satu julukan untuk mahasiswa adalah "Social Control". Social Control yang dimaksud adalah mahasiswa diharapkan menjadi pengontrol kehidupan masyarakat saat sekarang ini. Dengan sebutan yang disematkan kepada mahasiswa ini banyak dari mahasiswa ini bertindak diluar batas etika dan moral. Salah satu contoh yang terjadi di Universitas Sebelas Maret (UNS) dengan demo yang diinisiasi oleh BEM yang menjadikan trending topic Twitter nomor satu di Indonesia dengan hastag \#UniversitasNgaweSusah (Mardiastuti, 2020). Dalam kasus diatas etika mahasiswa milenial dalam berkomunikasi sudah kebablasan dan memperburuk kondisi dengan adanya pandemi Covid-19 yang merebak akhir-akhir ini. Potret sikap mahasiswa semacam ini banyak kita jumpai di dalam kampus. Mereka merealisasikan sikap ketidaksukaannya dengan berbagai bentuk, dari yang sepele mulai tidak mendengarkan dosen ketika mengisi materi sampai berulah dengan cara keluar 
saat kelas berlangsung hingga yang ekstrem melakukan demo dengan mengeluarkan kata-kata yang tidak menunjukan nilai sopan santun.

Mahasiswa sebagai agen perubahan perlu pembekalan nilai yang digunakan sebagai modal yang kuat dalam mebentuk norma agama dan norma sosial agar terbentuk karakter dan integritas yang kuat. Aksi diatas terlihat kurang memperhatikan etika dan estetika serta nilai sosial budaya. Etika dalam berkomunikasi tidak hanya berdasarkan pada kecerdasan intelektual semata, melainkan kecerdasan emosional juga sangat penting dalam pembentukan hubungan manusia dalam berkomunikasi.

Mahasiswa sebagai aset masa depan bangsa haruslah memeiliki integritas dan pendidikan karakter. Pendidikan dan karakter tidak dapat dipisahkan satu sama lain. pendidikan karakter pada dasarnya sudah lama ada di Indonesia. Sejak awal kemerdekaan, masa orde baru lama, orde baru hingga masa reformasi sudah banyak langkah-langkah yang diterapkan dalam membentuk pendidikan karakter dengan nama dan sebutan yang berbeda-beda. Dalam Undang-undang tentang pendidikan nasional yang pertama kali, ialah UU 1946 yang berlaku tahun 1947 hingga UU Sisdiknas Nomor 20 tahun 2003. pada Undang-Undang Sisdiknas pendidikan karakter sudah ada dalam Undang-Undang tetapi pelum menajdi fokus utama pendidikan (Susanti. 2013:481). Pendidikan karakter yang tidak optimal dapat dilihat dari peristiwa-peristiwa diatas. Padahal masyarakat timur memiliki adab sopan santun yang terbiasa santun dalam berprilaku dan bersilap, menyeselesaikan masalah dengan musyawarah dan mufakat Kaya akan kearifan lokal dengan menjunjung tinggi pluralitas, sangat toleran terhadap sesama dan gontong royong kini cenderung tindakanya berubah menjadi lebih individualistic dan saling menjatuhkan antar sesama serta berperilkau yang tidak jujur. Dengan fenomena semacam ini membuat pendidikan karakter terhadap mahasiswa sang perlu tidak hanya diterapkan di dalam jenjang SD, SMP, dan SMA, tapi juga di tingkat Perguruan Tinggi. Dengan adanya fenomena seperti diatas, tulisan ini akan membahas bagaimana pendidikan karakter dapat diterpakn di kalangan mahasiswa, guna menghasilkan calon pemimpin bangsa yang tidak hanya mampu di bidang akademik, namun juga membentuk mahasiswa yang berbudi perkerti luhur serta menjunjung tinggi nilai yang ada di dalam kampus.

\section{METODE}

Pendekatan yang digunakan adalah pendekatan kualitatif, yaitu pendekatan yang tidak menggunakan perhitungan-perhitungan secara sistematis dan statistik, melainkan lebih menekankan pada kajian interpretatif. Metode yang digunakan adalah metode deskriptif. Tujuan dari penelitian deskriptif adalah untuk memberikan deskripsi, gambaran atau lukisan secara sistematis, faktual dan akurat, fakta-fakta, sifat-sifat serta hubungan antarfenomena yang diselidiki. Teknik pengumpulan data dalam penelitian menggunakan observasi langsung, komunikasi langsung, dokumentasi, dan studi literatur.

\section{HASIL DAN PEMBAHASAN}

\section{Pengertian Pendidikan Karakter}

Karakter adalah sifat yang dibawa sejak lahir oleh tiap-tiap individu dengan memiliki berbagai macam perbedaan dalam setiap individunya. Karakter lebih condong terhadap budi pekerti setiap individu ataupun nilai dan moral yang dibawanya semenjak lahir. Kata karakter berasal dari bahasa Yunani, yaitu "charassein", yang dapat diartikan to engrave yang berarti mengukir. Proses pembentukan karakter dapat diartikan sebagai 
mengukir di atas batu permata ataupun permukaan besi yang keras. Dari kiasan kata tersebut selanjutnya berkembang pengertian karakter yang diartikan sebagai kata khusus atau pola perilaku (an individual's pattern of behavior ... his moral contitution). Menurut Buchori (2007) Istilah karakter secara harfiah berasal dari bahasa Latin "Charakter", yang berarti: watak, tabiat, sifat-sifat kejiwaan, budi pekerti, kepribadian atau akhlak. Sedangkan menurut istilah, karakter diartikan sebagai sifat manusia pada umumnya dimana manusia mempunyai banyak sifat yang tergantung dari faktor kehidupannya sendiri.

Sementara dalam Kamus Bahasa Indonesia kata 'karakter' dapat diartikan sebagai tabiat, sifat-sifat kejiwaan, akhlak atau budi pekerti yang berbeda dari setiap individu satu dengan yang lainnya. Menurut pandangan Ki Hadjar Dewantara, karakter sebagai watak atau budi pekerti. Menurutnya budi pekerti adalah bersatunya antara gerak fikiran, perasaan, dan kehendak atau kemauan yang kemudian menimbulkan tenaga.

Dari definisi karakter tersebut dapat ditarik sebuah kesimpulan secara ringkas bahwa karakter adalah sikap, tabiat, akhlak, kepribadian yang stabil sebagai hasil proses konsolidasi secara progresif dan dinamis; sifat alami individu dalam menghadapi situasi tertentu secara bermoral; watak, tabiat, akhlak, atau kepribadian seseorang yang terbentuk dari hasil internalisasi berbgai kebajikan, yang diyakini dan digunakan sebagai landasan untuk cara pandang, berpikir, bersikap dan bertindak; sifatnya jiwa manusia, mulai dari angan-angan sampai menjelma menjadi tenaga.

Dari definisi karakter diatas. Pendidikan karakter juga dapat diajabarkan sebagai berikut. Menurut Kemendiknas (2011) Pendidikan karakter merupakan upaya dalam mebiasakan diri setiap individu dalam menerima kebiasaan-kebiasaan yang baik (habituation). dengan kebiasaan yang baik ini peserta didik diharapkan peserta didik cakap dalam bersikap dan bertindak berdasarkan nilai-nilai yang telah ditanamkan sehingga menjadi kepribadian yang baik serta dalam pembangunan karakter setiap individu dilaksanakan dengan pendekatan sistematik dan integrative dengan melibatkan keluarga, satuan pendidikan, pemerintah, masyarakat sipil, anggota legsilatif, media massa, dunia usaha, dan dunia industri

Menurut Murphy $(1998,22)$ pendidikan karakter merupakan pendidikan yang berdasarkan nilai-nilai, etika inti bermula pada yang masyarakat demokratis, khususnya, penghargaan, tanggung jawab, kepercayaan, keadilan dan kejujuran, kepedulian, dan kemasyarakatan kebajikan dan kewarganegaraan. Dari pengertian tersebut dapat diartikan bahwa pendidikan karakter mengacu pada proses penanaman nilai, berupa pemahaman-pemahaman, tata cara merawat dan menghidupi nilai-nilai itu, serta bagaimana seorang siswa memiliki kesempatan untuk dapat melatihkan nilai-nilai tersebut secara nyata.

Dari beberapa definisi pendidikan karakter merupakan pendidikan nilai, pendidikan budi pekerti, pendidikan moral, pendidikan watak, yang bertujuan mengembangkan kemampuan setiap individu sebagai peserta didik untuk merespon keputusan baik-buruk merawat apa yang baik, mewujudkan dan menebar kebaikan itu dalam kehidupan sehari-hari dengan sepenuh hati.

\section{Nilai Dalam Pendidikan Karakter}

Membentuk mahasiswa yang berkarakter kuat dengan nilai/moral yang baik maka diperlukan adanya suatu pendekatan penanaman nilai (inculcation approach). Pendekatan penanaman nilai ini pada dasarnya merupakan pendekatan yang memberi penekanan pada penanaman aspek nilai-nilai sosial dalam diri utamanya untuk mahasiswa hingga dapat diaplikasikan dan disebar kedalam masyarakat. Tujuan pendekatan penanaman nilai adalah dapat diterima nilai-nilai sosial tertentu oleh peserta didik, serta nilai-nilai peserta didik yang berubah sehingga tidak sesuai dengan nilai-nilai sosial yang diinginkan yang bertujuan pada perubahan yang lebih baik. 
Menurut Kemdikbud (2017) ada lima nilai yang menjadikan karakter utama berasal dari Pancasila, merupakan prioritas utama dalam pengembangan gerakan penguatan pendidikan karakter; yaitu religius, nasionalisme, integritas, kemandirian dan kegotong royongan. setiap nilai yang ada tidak dapat berdiri dan berkembang sendirisendiri, tetapi saling bersinambungan dan saling menguatkan antara satu sama lain, berkembang secara dinamis dan membentuk keutuhan pribadi yang lebih baik.

Nilai karakter religius menngambarkan setiap individu terhadap Tuhan yang Maha Esa yang dipraktekkan dalam perilaku dengan melaksanakan peribadatan sesuai agama yang dianut menjauhi larangan ajaran yang diyakini, menghormati dengan sesame individu meskipun berbeda agama, menjunjung tinggi sikap toleran terhadap pelaksanaan ibadah agama dan kepercayaan lain, hidup rukun saling berdampingan serta damai dalam bermasyarakat. Penerapan nilai karakter religius dalam setiap mahasiswa dapat ditunjukan pada sikap cinta damai dan toleransi.

Nilai karakter nasionalis dapat diimplementasikan kedalam cara berpikir, bersikap, dan berbuat yang berdasarkan kesetiaan, kepedulian, dan penghargaan yang tinggi terhadap bahasa, lingkungan fisik, sosial, budaya, ekonomi, dan politik bangsa, memposisikan kepentingan bangsa dan negara di atas kepentingan diri dan kelompoknya. Sikap nasionalis ditunjukkan melalui sikap apresiasi budaya bangsa sendiri, menjaga kekayaan budaya bangsa, rela berkorban, unggul, dan berprestasi, cinta tanah air, menjaga lingkungan, taat hukum, disiplin, menghormati keragaman budaya, suku, dan agama. Mahasiswa sebagai agen perubahan dapat berkontribusi dengan nilai nasionalisme terhadap bangsa yang dapat ditunjukkan dengan keseriusan menimba ilmu di bangku kuliah. Mahasiswa dapat mengasah keahlian dan spesialisasi pada bidang ilmu yang mereka pelajari di perguruan tinggi, agar dapat meluruskan berbagai ketimpangan sosial ketika terjun di masyarakat kelak.

Nilai karakter integritas yang dimaksud adalah nilai yang merupakan karakter sesorang individu yang memiliki pribadi yang jujur dan berkarakter kuat. Setiap individu memiki nilai integritas merupakan orang yang selalu dapat dipercaya dalam perkataan, tindakan, dan pekerjaan, memiliki komitmen dan kesetiaan pada nilai-nilai kemanusiaan dan moral. Karakter integritas termasuk juga memiliki tanggung jawab dan komitmen sebagai warga negara yang baik, selalu aktif dan terlibat langsung dalam kehidupan sosial bermasyarakat, dengan integrita ini dapat dilihat dengan konsistesnsi terhadap tindakan dan perkataan yang berdasarkan kebenaran. Seseorang yang berintegritas menjungjung tinggi sama rata martabat setiap individu (terutama penyandang disabilitas), serta dapat mencotohkan keteladanan yang dapat dicontoh oleh individu lainnya. Mahasiswa yang memiliki integritas merupakan mahasiswa yang berkarakter, berprinsip serta konsisten di dalam menjalankan kehidupan. Berintegritas dapat dimulai dari hal-hal kecil seperti berhati-hati dalam berucap, jujur serta selalu berusaha menepati janji. Orang yang sudah mengatakan akan hadir pada suatu rapat atau acara, tidak akan tidak hadir hanya karena hujan atau kemalasan. Orang yang berintegritas akan mengeluarkan usaha lebih terhadap suatu kondisi yang mungkin bisa menjadi alasan ketidak hadirannya.

Nilai karakter mandiri dapat diartikan dengan sikap dan perilaku yang berdiri sendiri dan tidak bergantung pada orang lain serta mempergunakan segala tenaga, pikiran, waktu untuk merealisasikan harapan, mimpi dan cita-cita. mahasiswa yang memiliki jiwa mandiri [ada dasarnya mempunyai etos kerja yang baik, tangguh, berdaya juang, profesional, kreatif, keberanian, dan menjadi pembelajar sepanjang hayat. Sikap kemandirian pada mahasiswa dapat terlihat dengan mahasiswa yang dapat mengatur hidupnya, dapat memanejemen waktu dan berkemampuan berfikir secara mandiri serta dapat memecahkan masalah yang sedang dihadapi dengan mandiri. Sikap ini seharusnya penting bagi mahasiswa sehingga dapat memiliki sifat mandiri dan berdikari.

Nilai karakter yang terakhir adalah nilai gotong royong yang dapat dilihat dalam sebuah tindakan yang menghargai semangat kerja sama dan saling bahu membahu 
dalam menyelesaikan setiap persoalan bersama, menjalin komunikasi dan persahabatan, memberi bantuan/pertolongan pada orang-orang yang membutuhkan. Dengan nilai karakter gotong royong diharapkan mahasiswa dapat mengaplikasikan nilai gotong royong kedalam sikap menghargai sesama, dapat bekerja sama, inklusif, mampu berkomitmen atas keputusan bersama, musyawarah mufakat, tolong menolong, memiliki empati dan rasa solidaritas, anti diskriminasi, anti kekerasan, dan sikap kerelawanan.

\section{Implementasi Pendidikan Karakter pada Mahasiswa}

Perguruan tinggi sebagai tempat menimba ilmu bagi mahasiswa sehingga dapat menghasilkan karya-karya, selain sebagai tempat menimba ilmu, Universitas juga tempat pemecahan berbagai masalah, tempat mengkritisi karya-karya yang dihasilkan, dan sebagai pusat pelatihan manusia. Mahasiswa sebagai agen perubahan dituntuk memeliki pemikiran-pemikiran yang maju sehingga menghasilkan lulusan yang memiliki nalar tinggi analisa yang luas dan tajam, berilmu tinggi dan berprilaku terpuji.

Penerapan pendidikan karakter dalam kalangan mahasiswa dinilai cukup sulit dikarenakan beberapa hal yang belum selaras. Schwartz (2000) dalam pendapatnya menyatakan ada beberapa hal yang dirasa keliru dalam pelaksanaannya pendidikan karakter dilingkupan mahasiswa, antara lain 1. Karakter setiap individu yang terbentuk terbentuk pada masa kecil sebelum mahasiswa masuk ke perguruan tinggi dan pendidikan karakter pada masa kecil dulunya masih menjadi tanggung jawab orang tua masing-masing dalam pembentukan karakter anaknya. 2. Di dalam perguruan tinggi, bagi dosen yang tidak memiliki tanggung jawab dengan pembentukan karakter karena pada dasarnya untuk melakukan hal tersebut dosen tidak ada kaitannya. 3. Karakter merupakan istilah yang mengacu pada agama tau ideology konservatif tertentu, sementara itu perguruan tinggi di barat secara umum melepaskan diri dari agama atau idiologi tertentu.

Perguruan tinggi dapat membuat beberapa kegiatan yang dapat menguatkan pendidikan karakter. Kegiatan yang pertama adalah perlunya di dalam area perguruan tinggi melakukan perubahan struktur kognisi agar para mahasiswa paham dengan adanya arti sebuah nilai. Dengan paham arti nilai ini para mahasiswa, kedepannya paham akan kesiapan dan kesadaran dalam menyerap tata nilai itu, sehingga dapa dicerna menjadi miliknya sendiri (internalisasi nilai). Kesadaran dan internalisasi nilai yang diawali dengan pahamnnya tata nilai (struktur kognisi) akan mempunyai daya yang asli, sebagaimana dihasilkan dari sebuah proses pembelajaran (learned behavior). Proses pembelajaran dengan pembelajaran pendidikan karakter dinilai sangat mendesak untuk ditegakkan kembali pendidikan karakter di perguruan tinggi melalui Mata Kuliah Wajib Umum (MKWU). Pengamalan pendidikan karakter bisa dapat dinilai berhasil bilamana terpadu kedalam pengorganisasian materi, metode, media, dan alat evaluasi dengan aspek-aspek pendidikan karakter yang meliputi olah pikir, olah hati, olah rasa, dan olah raga. internalisasi nilai diisi dengan mata kuliah menggunakan dialog sehingga dapat menjadi efektif jika potensi pikir peserta didik dengan tata nilai yang disajikan oleh warga kampus.

Kedua melalui pendekatan intuisi. Pendekatan ini menekankan pada kemampuan setiap individu mahasiswa serta pengalaman subyektifnya juga. Pendekatan intuisi ini, para mahasiswa diarahkan kedalam imajinasi dan perasaan pada nilai juang serta tata nilai kampus. Pendekatan Behavior Moral Development memandang bahwa internalisasi nilai dilakukan melalui pembiasaan (conditioning/habituation). Pendekatan ini bermula dari percobaan yang dilakukan oleh Ivan Pavlov pada seekor binatang, akan tetapi pendekatan ini sangat relevan dengan upaya penanaman nilai. Seorang mahasiswa yang dibiasakan tertib dan berperilaku baik dalam kehidupan sehari-harinya, pada akhirnya akan terbiasa melakukan hal-hal tersebut. Pada gilirannya nanti kebiasaan-kebiasaan yang dilakukannya tersebut akan 
mengendap menjadi tata nilai milik dirinya sendiri. Manakala mereka melakukan suatu tindakan di luar kebiasaannya, mereka akan merasa bersalah.

Pembiasaan merupakan sebuah metode yang mengamalkan nilai yang tetap tinggu efektifitasnya, apalagi apabila kegiatan tersebut terdapat reward and punishment dalam pelaksanaannya pendekatan pembinaan nilai apabila dilakukakn terus menerus akan menghasilkan efektifitas tinggi. Dengan kata lain pembinaan karakter (character building) apabila dilakukan secara menyeluruh dan terus menerus akan berhasil. pembinaan tersebut terdiri atas perubahan struktur kognisi, singgungan emosional, dan penciptaan lingkungan kampus yang kondusif. Area kampus sebagai tempat tumbuh kembang character building para mahasiswa, dalam perjalannya menghasilkan daya yang dapat berkontribusi pada proses dan hasil, sehingga dibutuhkan sinergitas dalam proses pembinaan dari seluruh civitas kampus. Salah satu kegiatan yang menunjang karakter building mahasiswa adalah Pengenalan Kehidupan Kampus Bagi Mahasiswa Baru (PKKMB). PPKMB yang bertujuan untuk mengenalkan mahasiswa dengan lingkungan kampus. PKKMB merupakan tempat bagi pemimpin perguruan tinggi untuk memperkenalkan dan mempersiapkan mahasiswa baru dalam proses transisi dari siswa menjadi mahasiswa serta diisi dengan berbagai kegiatan yang berkaitan dengan penanaman wawasan kebangsaan, cinta tanah air, bela negara dan pembentukan karkater mahasiswa yang aktif, mandiri dan berintergritas.

\section{SIMPULAN}

Pembentukan karakter sangat diperlukan di jenjang perguruan tinggi guna membangun mahasiswa menjadi pribadi yang berkarakter kuat dan dapat mengaplikasikanya pada kehidupan sehari-hari. Pembiasaan pendidikan karakter dalam diri mahasiswa harus dilakukan terus menerus dan efektifan tinggi sehingga mahsiswa dapat mengaplikasikan pada kehidupan sehari-hari, bermasyarakat dan sebagai warga negara yang baik.

Implementasi pendidikan karakter tidak hanya kewajiban mahasiswa saja tetapi seluruh citivas akademika juga bekerja sama membangun sebuah atsmorfer pendidikan yang berkarakter. Tidak hanya hal ini orangtua dan masyarakat juga perlu berkontribusi dalam membangun lingkungan yang berkarakter kuat. Perguruan tinggi dalam membangun pendidikan karakter dengan cara memperkuat mata kuliah wajib umum (MKWU) serta membangun pendidikan karakter sejak awal masuk perguruan tinggi dengan PPKMB.

\section{DAFTAR PUSTAKA}

Buchori, Mochtar. Buku Panduan Internalisasi Pendidikan karakter di Sekolah, Yogyakarta : Penerbit Diva Prees, 2007.

Kemendikbud. 2017. "Penguatan Pendidikan Karakter Jadi Pintu Masuk Pembenahan Pendidikan Nasional". (https://www.kemdikbud.go.id/main/ blog/2017/07/penguatan-pendidikan-karakter-jadi-pintu-masuk-pembenahanpendidikan-nasional). (Diakses pada hari Senin, 20 Agustus 2020 pukul 9.45 WIB).

Kemendiknas. Panduan Pendidikan Karakter. Jakarta: Puskur-Balitbang, 2011.

Kemendiknas. Pengembangan Pendidikan Budaya dan Karakter Bangsa.Jakarta: Kementrian Pendidikan Nasional, 2010. 
Kementrian Pendidikan Nasional. Kurikulum Tingkat Satuan Pendidikan Sekolah Dasar. Jakarta: BSNP, 2011.

Mardiyastuti, Aditya. 2020. Demo \#UniversitasNggaweSusah di UNS Terapkan Physical Distancing. https://news.detik.com/berita-jawa-tengah/d-5100978/demouniversitasnggawesusah-di-uns-terapkan-physical-distancing. (Diakses pada hari Senin, 20 Agustus 2020 pukul 9.50 WIB)

Murphy, M. Character Education in America's Blue Ribbon Schools Lancaster. PA: Technomic Publishing, 1998

Ramli, T. Pendidikan Karakter. Bandung : Angkasa, 2003.

Schwartz, AJ. It's Not to Late to Teach College Student about Values. The Chronicle of Higher Education. (2000) Vol 46. No 40.

Susanti, R. (2013). Penerapan Pendidikan Karakter di Kalangan Mahasiswa. Jurnal AlTa'lim. (2013) vol: 1 no: 6. 